\title{
Gene Expression Analysis of Pancreatic Cell Lines Reveals Genes Overexpressed in Pancreatic Cancer
}

\author{
Ingo Alldinger a,c,1 Dag Dittert ${ }^{\mathrm{b}, 1}$ Matthias Peiper ${ }^{\mathrm{c}}$ Alberto Fusco ${ }^{\mathrm{d}}$ \\ Gennaro Chiappetta $^{\text {e }}$ Eike Staub $^{f}$ Matthias Löhrg Ralf Jesenofsky ${ }^{g}$ \\ Gustavo Baretton $^{b}$ Detlef Ockert ${ }^{a}$ Hans-Detlev Saeger ${ }^{a}$ \\ Robert Grützmanna,2 Christian Pilarskya,2
}

Departments of a Visceral-, Thoracic- and Vascular Surgery, and 'Pathology, University Hospital, Dresden, and 'Department of General and Visceral Surgery, University Hospital, Düsseldorf, Germany, ${ }^{\mathrm{d} C e n t r o ~ d i ~ E n d o c r i n o l o g i a ~}$ ed Oncologia Sperimentale del CNR, c/o Dipartimento di Biologia e Patologia Cellulare e Molecolare, Università di Napoli Federico II, Naples, and e Department of Experimental Oncology, Istituto dei Tumori, Naples, Italy, ${ }^{f}$ metaGen Pharmaceuticals, Berlin, and ${ }^{9}$ Medical Department, University Hospital, Mannheim, Germany

\section{Key Words}

Pancreas · Cancer · Cell line · Primary isolates •

Microarray $\cdot$ Thymosin $\cdot$ Immunohistochemistry

\begin{abstract}
Background: Pancreatic cancer is one of the leading causes of cancer-related death. Using DNA gene expression analysis based on a custom made Affymetrix cancer array, we investigated the expression pattern of both primary and established pancreatic carcinoma cell lines. Methods: We analyzed the gene expression of 5 established pancreatic cancer cell lines (AsPC-1, BxPC-3, Capan-1, Capan-2 and HPAF II) and 5 primary isolates, 1 of them derived from benign pancreatic duct cells. Results: Out of 1,540 genes which were expressed in at least 3 experiments, we found 122 genes upregulated and 18 downregulated in tumor cell lines compared to benign
\end{abstract}

Authors contributed equally.

Authors share senior authorship. cells with a fold change $>3$. Several of the upregulated genes (like Prefoldin 5, ADAM9 and E-cadherin) have been associated with pancreatic cancer before. The other differentially regulated genes, however, play a so far unknown role in the course of human pancreatic carcinoma. By means of immunohistochemistry we could show that thymosin $\beta-10$ (TMSB10), upregulated in tumor cell lines, is expressed in human pancreatic carcinoma, but not in non-neoplastic pancreatic tissue, suggesting a role for TMSB10 in the carcinogenesis of pancreatic carcinoma. Conclusion: Using gene expression profiling of pancreatic cell lines we were able to identify genes differentially expressed in pancreatic adenocarcinoma, which might contribute to pancreatic cancer development.

Copyright (c) 2005 S. Karger AG, Basel and IAP

\section{Introduction}

Pancreatic cancer is the fourth leading cause of cancer death in the United States. It can be estimated that annually 28,000 people die from pancreatic cancer [1].

\begin{tabular}{ll}
\hline KARGER & ( ) 2005 S. Karger AG, Basel and IAP \\
Fax +4161306 1234 $34-3903 / 05 / 0055-0370 \$ 22.00 / 0$ \\
$\begin{array}{l}\text { E-Mail karger@karger.ch } \\
\text { www.karger.com }\end{array}$ & $\begin{array}{l}\text { Accessible online at: } \\
\text { www.karger.com/pan }\end{array}$
\end{tabular}

Dr. Christian Pilarsky

Department of Visceral-, Thoracic- and Vascular Surgery

University Hospital Dresden, Fetscherstrasse 74

DE-01307 Dresden (Germany), Tel. +49 3514582246

Fax +49351458 4395, E-Mail christian.pilarsky@mailbox.tu-dresden.de 
The incidence has slightly increased over the past decades, being 8.1 for men and 5.4 for women in Germany [2]. About $80 \%$ of patients with pancreatic carcinoma present with an irresectable tumor at the time of diagnosis. Chemotherapy and radiation have not been able to increase the survival rate, and curability of the disease strongly depends on early diagnosis. Although several molecular alterations have been associated with pancreatic carcinoma, a much larger number of genes are involved in processes leading to cell transformation and, in consequence, pancreatic cancer.

DNA microarray technology has proven to be a useful tool to screen the differential mRNA expression pattern of normal and carcinoma cells [3-7]. While for other tumor entities a small piece from the tumor can be excised, homogenized and the mRNA extracted to be analyzed, the morphological growth peculiarities of pancreatic carcinoma impede this approach. Due to the characteristic host desmoplastic reaction to the tumor, only a small fraction of the mRNA extracted from carcinomatous tumor will descend from the transformed ductal cells. A majority will represent the expression profile of the surrounding stromal cells. Cell lines can, however, be used as model systems for tumor development and for the analysis of new treatment options. We therefore determined the differential gene expression in pancreatic carcinoma from established tumor cell lines and primary isolates using a custom made Affymetrix GeneChip. Within the set of genes we identified 140 genes as differentially expressed and validated the overexpression of thymosin $\beta-10$ (TMSB10) within ductal pancreatic adenocarcinomas by immunohistochemistry.

\section{Materials and Methods}

\section{Cell Lines and RNA Preparation}

The ATCC (American Type Culture Collection) cell lines AsPC-1 (CRL-1682), BxPC-3 (CRL-1687), Capan-1 (HTB-79), Capan-2 (HTB-80) and HPAF II (CRL-1997) were a gift from Dr. M. Schmitz, Institute of Immunology, University of Dresden.

UKEAC-99 was obtained from a patient who underwent Whipple's operation for papillary carcinoma of intermediate differentiation [8]. PI3 was obtained from a metastasis in the omentum of a patient with pancreatic adenocarcinoma of intermediate differentiation. PI4 was derived from ascites fluid of a patient with pancreatic adenocarcinoma, and PI5 was obtained from a lung metastasis from a patient with pancreatic adenocarcinoma. All cell lines were tested for tumorigenicity and caused pancreatic adenocarcinoma after injection into mice which were histologically confirmed by a pathologist. Chromosomal analysis was performed with all cell lines.
ATCC cells and primary isolates were propagated in RPMI 1640 medium (Gibco) supplemented with 10\% fetal bovine serum (Gibco), $2 \mathrm{~m} M$ glutamine (Gibco), nonessential amino acids ( $5 \mathrm{ml} / \mathrm{l})$, and penicillin/streptomycin $(10,000$ units/ml penicillin and $10 \mathrm{mg} / \mathrm{ml}$ streptomycin, $10 \mathrm{ml} / 1$ medium; Sigma) and passaged before confluency.

The hPDC was obtained from the main pancreatic duct of a patient undergoing surgery for chronic pancreatitis. The cells were propagated in Keratinocyte SFM supplemented with $5 \mathrm{ng} / \mathrm{ml} \mathrm{EGF,}$ $50 \mu \mathrm{g} / \mathrm{ml} \mathrm{BPE}, 50 \mu \mathrm{g} / \mathrm{ml}$ gentamycin, $0.25 \mu \mathrm{g} / \mathrm{ml}$ Fungizone; $500 \mu \mathrm{l} /$ $60 \mathrm{~mm}$ dish (Invitrogen, Karlsruhe, Germany) [9]. All cells were lysed in a guanidine thiocyanate buffer with $2 \% \beta$-mercaptoethanol added (Promega, Heidelberg, Germany).

Poly A ${ }^{+}$RNA was prepared with a PolyATtract 1000 kit (Promega) according to the manufacturer's recommendations. For each sample the cDNA synthesis and in vitro transcription were performed according to the Affymetrix user manual using $500 \mathrm{ng}$ of the isolated RNA. In brief, cDNA synthesis was initiated using the Affymetrix T7-oligo-dT promotor-primer combination at $0.1 \mathrm{~m} M$. From this first strand cDNA, the second strand synthesis was generated with internal priming. The in vitro transcription was performed with Ambion's Megascript kit (Ambion, Huntington, UK), as recommended by the manufacturer. During the in vitro transcription, biotin-labeled nucleotides were incorporated into the aRNA. Hybridization and detection of the labeled aRNA on the metg001A GeneChip were performed according to Affymetrix's instructions.

\section{Chip Design and Data Analysis}

The custom metg001A GeneChip used in this study consists of 6,117 probe sets resembling $3,023 \mathrm{cDNA}$ fragments. The cDNA fragments were chosen from a data mining approach to characterize the expression of cancers by an electronic Northern blot $[10,11]$. In addition genes of signal transduction cascades, which are implicated in cancer development and progression, like the wnt cascade, were selected.

The background was computed as the mean of the $2 \%$ darkest feature intensities. After background correction the arrays were normalized by dividing each feature of a given GeneChip by the median value derived from all features of the same GeneChip. To generate the representative expression value we used the $75 \%$ quartile of the ranked intensities from the 20 perfect-matching oligonucleotides of a probe set, in an approach similar to that of Irizarry et al. [12]. To distinguish signal from noise we applied the Wilcoxon signed rank test to each probe set. The probe set was labeled as present if the result of the Wilcoxon signed rank was below 0.01 .

To determine the relative difference in expression between the tumor cell lines and the benign ductal cells, the mean expression value in the tumor cell lines was calculated and compared to the expression value in the benign ductal cells. Genes were called as differentially expressed when the change fold was above 3 and when the gene was called present in at least 3 cell lines as well. Genes are listed according to the difference ratio.

Complete linkage clustering of the differentially expressed genes was done using the Genecluster/Treeview software package (http:// rana.lbl.gov/EisenSoftware.htm) using Spearman rank correlation as distance matrix (fig. 1).

\section{Immunohistochemical Staining}

Tumor tissue was selected from 55 consecutive cases of pancreatic ductal adenocarcinoma, whereas adenocarcinoma of the ampulla 
of Vater or the distal ductus choledochus was not included. Patients were operated on at ages from 34 to 80 years; 27 were male and 28 were female.

Four-micron sections were cut from the formalin-fixed, paraffinembedded, pancreatic adenocarcinoma tissue. The sections were mounted on superfrost slides (Menzel Gläser, Braunschweig, Germany), dewaxed with xylene and gradually hydrated. Antigen was exposed by heating the sections under high pressure in Tris-EDTAcitrate buffer. The primary goat polyclonal anti-human TMSB10 antibody [13] was diluted 1:500 in PBS containing 2\% horse serum (Vector Laboratories, Burlingame, Calif., USA). After incubation for $45 \mathrm{~min}$, the reaction was visualized with a biotinylated anti-goat antibody $(5 \mu \mathrm{g} / \mathrm{ml}$, Vector Laboratories) and avidin-biotin-peroxidase (ABC ELITE, Vector Laboratories). Diaminobenzidine served as chromogen. Afterwards the slides were briefly counterstained with hematoxylin. The primary antibody was omitted for the negative control. Unspecific goat IgG at the same concentration as the specific Ig were used as isotype controls to assure the specificity of the reaction. Staining intensity was evaluated semi-quantitatively as negative, weak, moderate or strong. The final results, however, were recorded as positive or negative staining only.

\section{Results}

Out of the 3,023 cDNA fragments interrogated by gene expression profiling 1,540 genes were rated as present in at least 3 cell lines. Difference in expression was rated significant if the ratio was greater than 3 and if the gene was detected as present in at least 3 cell lines as well. Of the 1,540 genes, 122 were upregulated and 18 were downregulated in respect to the benign cells. Seven genes were upregulated and 3 genes downregulated in primary isolates only. One gene was upregulated in ATCC cell lines only and not in primary isolates (table 1).

Using hierarchical clustering, we generated a heat map of the gene expression of the identified genes to visualize the gene expression within each experiment (fig. 1). Genes encoding proteins of known function have been classified according to functional categories (fig. 2). Within these categories we found that genes associated with cellular proliferation are commonly upregulated. Within the 122 genes we identified several genes, such as ADAM9 or Ecadherin, with known function in carcinoma of the pancreas or other tissues (table 2).

Fig. 1. Hierarchical clustering of differentially expressed genes in pancreatic cells. Black squares indicate that the gene was called absent by the software.

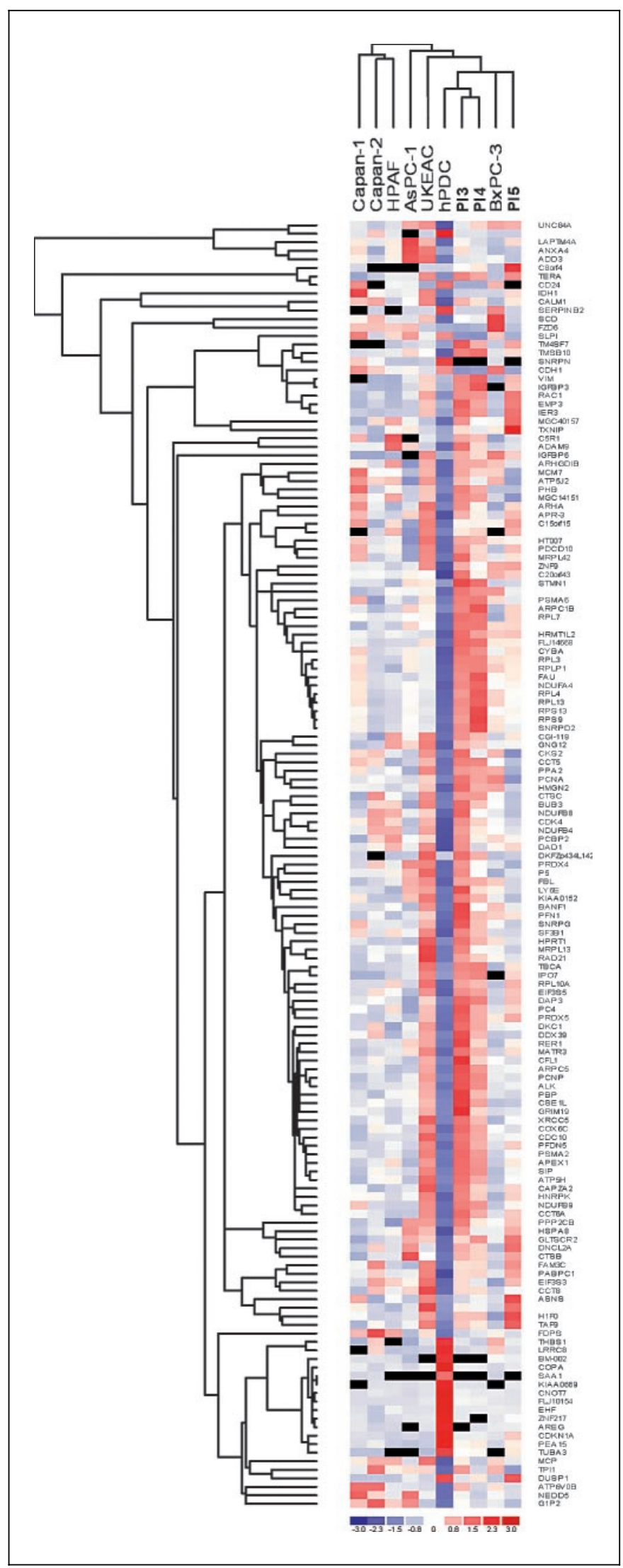

Alldinger et al. 
Table 1. Genes differentially expressed within the pancreatic cell lines analyzed

A. Genes upregulated in tumor

\begin{tabular}{|c|c|c|c|c|c|c|c|c|c|c|c|c|}
\hline Name & Symbol & Unigene ID & $\mathrm{MV} / \mathrm{hPDC}$ & BxPC-3 & AsPC-1 & Capan-1 & Capan-2 & HPAF2 & PI1 & PI3 & PI4 & PI5 \\
\hline CDC28 protein kinase regulatory subunit 2 & CKS2 & Hs. 83758 & 12.11 & 15.15 & 6.87 & 12.88 & 14.36 & 9.50 & 17.58 & 20.53 & 9.75 & 2.32 \\
\hline Thymosin $\beta-10$ & TMSB10 & Hs.76293 & 12.08 & 9.47 & 12.60 & 8.83 & 9.40 & 10.13 & 10.89 & 17.13 & 17.88 & 12.40 \\
\hline Similar to transmembrane protein AMIGO3 & - & Hs. 121520 & 10.13 & 5.88 & 6.84 & 10.03 & 5.67 & 3.52 & 21.84 & 10.11 & 8.60 & 18.69 \\
\hline CSE1 chromosome segregation 1-like (yeast) & CSE1L & Hs. 90073 & 9.59 & 5.00 & 8.35 & 6.89 & 8.89 & 6.89 & 11.91 & 19.69 & 13.42 & 5.27 \\
\hline \multicolumn{13}{|l|}{ Capping protein (actin filament) } \\
\hline muscle Z-line, $\alpha_{2}$ & CAPZA2 & Hs.75546 & 9.52 & 6.19 & 7.46 & 8.39 & 4.58 & 6.22 & 16.97 & 14.90 & 10.53 & 10.47 \\
\hline $\begin{array}{l}\text { Eukaryotic translation initiation factor } 3, \\
\text { subunit } 3 \gamma, 40 \mathrm{kDa}\end{array}$ & EIF3S3 & Hs.58189 & 9.48 & 4.16 & 9.06 & 6.98 & 12.16 & 10.22 & 14.32 & 9.85 & 7.59 & 11.02 \\
\hline Small nuclear ribonucleoprotein polypeptide $\mathrm{G}$ & SNRPG & Hs. 77496 & 9.39 & 8.33 & 6.89 & 10.82 & 7.54 & 7.71 & 11.25 & 15.11 & 10.69 & 6.17 \\
\hline Prefoldin 5 & PFDN5 & Hs. 288856 & 9.22 & 6.91 & 6.33 & 6.12 & 6.36 & 8.18 & 13.18 & 14.29 & 11.37 & 10.23 \\
\hline Asparagine synthetase & ASNS & Hs. 75692 & 8.65 & 5.55 & 4.14 & 12.45 & 2.25 & 7.68 & 14.78 & 5.05 & 7.29 & 18.68 \\
\hline Calmodulin 1 (phosphorylase kinase, $\delta$ ) & CALM1 & Hs. 374441 & 7.91 & 4.89 & 7.19 & 8.80 & 9.57 & 5.45 & 10.59 & 9.17 & 7.83 & 7.70 \\
\hline Proliferating cell nuclear antigen & PCNA & Hs.78996 & 7.42 & 11.41 & 4.99 & 5.51 & 6.65 & 5.84 & 8.30 & 12.16 & 10.13 & 1.79 \\
\hline Cyclin-dependent kinase 4 & CDK4 & Hs. 95577 & 7.35 & 6.64 & 4.81 & 7.07 & 8.95 & 7.57 & 8.43 & 9.53 & 7.69 & 5.46 \\
\hline Dyskeratosis congenita 1 , dyskerin & $\mathrm{DKC1}$ & Hs. 4747 & 7.24 & 6.04 & 6.28 & 4.94 & 8.05 & 3.23 & 9.70 & 11.38 & 9.12 & 6.39 \\
\hline $\begin{array}{l}\text { Zinc finger protein } 9 \text { (a cellular retroviral } \\
\text { nucleic-acid-binding protein) }\end{array}$ & \multicolumn{9}{|c|}{ Zinc finger protein 9 (a cellular retroviral } & 8.47 & 6.54 & 8.80 \\
\hline \multicolumn{13}{|l|}{ Complement component 5 receptor 1} \\
\hline (C5a ligand) & $\mathrm{C} 5 \mathrm{R} 1$ & Hs. 2161 & 7.15 & 0.43 & & 11.57 & 1.39 & 17.72 & 5.63 & 12.30 & 10.67 & 4.68 \\
\hline \multicolumn{13}{|l|}{ NADH dehydrogenase (ubiquinone) } \\
\hline $1 \alpha$ subcomplex, $4,9 \mathrm{kDa}$ & NDUFA4 & Hs.50098 & 7.04 & 6.38 & 6.52 & 6.87 & 5.27 & 5.76 & 6.12 & 9.48 & 10.37 & 6.62 \\
\hline Mitochondrial ribosomal protein L13 & MRPL13 & Hs. 333823 & 6.93 & 6.04 & 6.46 & 4.39 & 6.08 & 5.42 & 12.74 & 10.33 & 6.50 & 4.40 \\
\hline Profilin 1 & PFN1 & Hs.408943 & 6.82 & 7.48 & 5.40 & 4.42 & 6.04 & 4.12 & 7.49 & 11.64 & 7.91 & 6.85 \\
\hline Hypothetical protein MGC40157 & MGC40157 & Hs. 295362 & 6.67 & 5.98 & 5.82 & 3.44 & 6.86 & 8.44 & 4.14 & 9.00 & 6.10 & 10.26 \\
\hline $\begin{array}{l}\text { A disintegrin and metalloproteinase domain } 9 \\
\quad(\text { meltrin } \gamma)\end{array}$ & ADAM9 & Hs. 2442 & 6.67 & 4.47 & 7.26 & 5.72 & 5.73 & 10.26 & 4.50 & 9.96 & 6.90 & 5.21 \\
\hline $\begin{array}{l}\text { Finkel-Biskis-Reilly murine sarcoma virus } \\
\text { (FBR-MuSV) ubiquitously expressed } \\
\text { (fox derived); ribosomal protein S30 }\end{array}$ & FAU & Hs. 177415 & 6.66 & 6.20 & 4.77 & 6.76 & 4.94 & 5.37 & 5.72 & 9.02 & 10.68 & 6.51 \\
\hline PEST-containing nuclear protein & PCNP & Hs.71618 & 6.61 & 5.41 & 5.58 & 3.49 & 4.98 & 3.82 & 9.36 & 12.11 & 9.95 & 4.78 \\
\hline Epithelial membrane protein 3 & EMP3 & Hs.9999 & 6.59 & 2.73 & 2.69 & 1.24 & 3.08 & 1.59 & 8.94 & 15.04 & 10.72 & 13.24 \\
\hline RAD21 homolog (S. pombe) & RAD21 & Hs. 81848 & 6.58 & 6.22 & 5.27 & 3.99 & 5.94 & 4.27 & 12.34 & 8.84 & 7.38 & 5.01 \\
\hline Ribosomal protein L10a & RPL10A & Hs. 425293 & 6.50 & 4.14 & 4.72 & 4.85 & 4.82 & 6.89 & 9.70 & 8.22 & 7.47 & 7.72 \\
\hline Isocitrate dehydrogenase $1(\mathrm{NADP}+)$, soluble & IDH1 & Hs. 11223 & 6.27 & 4.23 & 5.43 & 11.53 & 5.90 & 5.00 & 9.31 & 4.11 & 4.29 & 6.62 \\
\hline \multicolumn{13}{|l|}{ High-mobility group nucleosomal-binding } \\
\hline domain 2 & HMGN2 & Hs. 181163 & 6.18 & 7.59 & 5.22 & 5.45 & 5.21 & 4.46 & 6.86 & 9.06 & 7.35 & 4.43 \\
\hline \multicolumn{13}{|l|}{ DEAD/H (Asp-Glu-Ala-Asp/His) } \\
\hline box polypeptide 39 & DDX39 & Hs. 311609 & 6.14 & 3.52 & 4.86 & 5.49 & 7.37 & 2.98 & 8.26 & 11.36 & 7.65 & 3.78 \\
\hline \multicolumn{13}{|l|}{ NADH dehydrogenase (ubiquinone) } \\
\hline $1 \beta$ subcomplex, $8,19 \mathrm{kDa}$ & NDUFB8 & Hs. 198273 & 5.90 & 4.88 & 5.00 & 4.28 & 7.50 & 7.08 & 6.32 & 8.96 & 5.35 & 3.67 \\
\hline Fibrillarin & FBL & Hs. 99853 & 5.77 & 6.28 & 6.84 & 3.79 & 4.29 & 4.88 & 7.59 & 7.08 & 6.91 & 4.27 \\
\hline \multicolumn{13}{|l|}{ Proteasome (prosome. macropain) } \\
\hline subunit, $\alpha$ type, 2 & PSMA2 & Hs.411773 & 5.54 & 3.70 & 3.34 & 4.43 & 3.79 & 4.60 & 8.39 & 9.01 & 7.58 & 5.02 \\
\hline Hypothetical protein FLJ14668 & FLJ14668 & Hs. 334644 & 5.51 & 5.43 & 4.06 & 4.64 & 3.85 & 4.03 & 5.54 & 8.45 & 8.16 & 5.40 \\
\hline \multicolumn{13}{|l|}{ Neural precursor cell expressed, } \\
\hline Splicing factor $3 \mathrm{~b}$, subunit $1,155 \mathrm{kDa}$ & SF3B1 & Hs. 334826 & 5.35 & 4.15 & 4.76 & 5.56 & 4.28 & 5.35 & 7.03 & 7.03 & 5.93 & 4.07 \\
\hline Ras homolog gene family, member A & ARHA & Hs. 77273 & 5.25 & 2.14 & 3.96 & 7.55 & 4.38 & 2.56 & 8.40 & 7.53 & 5.10 & 5.60 \\
\hline Apoptosis-related protein APR-3 & APR-3 & Hs.9527 & 5.23 & 4.00 & 5.43 & 5.89 & 4.29 & 3.92 & 6.72 & 5.99 & 5.02 & 5.83 \\
\hline Triosephosphate isomerase 1 & TPI1 & Hs. 83848 & 5.21 & 6.16 & 5.27 & 4.36 & 7.60 & 5.08 & 5.54 & 6.73 & 3.82 & 2.34 \\
\hline H1 histone family, member 0 & H1F0 & Hs. 226117 & 5.20 & 1.46 & 3.87 & 4.69 & 3.14 & 3.35 & 7.37 & 6.39 & 6.41 & 10.15 \\
\hline TAF9 RNA polymerase II, TATA-box-binding & & & & & & & & & & & & \\
\hline protein (TBP)-associated Factor, $32 \mathrm{kDa}$ & TAF9 & Hs. 60679 & 5.17 & 3.16 & 4.53 & 2.64 & 4.94 & 3.43 & 7.89 & 5.98 & 5.22 & 8.79 \\
\hline Thioredoxin-interacting protein & TXNIP & Hs. 179526 & 5.16 & 5.30 & 5.40 & 3.15 & 1.65 & 5.01 & 3.14 & 5.57 & 3.87 & 13.31 \\
\hline Cytochrome $b-245, \alpha$ polypeptide & CYBA & Hs. 68877 & 5.13 & 4.53 & 4.95 & 5.43 & 3.89 & 4.19 & 4.50 & 7.07 & 6.50 & 5.12 \\
\hline Lymphocyte antigen 6 complex, locus E & LY6E & Hs. 77667 & 5.13 & 4.96 & 6.29 & 3.91 & 3.70 & 2.68 & 6.75 & 8.91 & 5.29 & 3.64 \\
\hline Similar to $S$. cerevisiae RER 1 & RER1 & Hs. 40500 & 5.03 & 2.80 & 5.53 & 3.29 & 3.92 & 3.91 & 6.53 & 9.09 & 5.33 & 4.90 \\
\hline Ribosomal protein L4 & RPL4 & Hs. 286 & 5.01 & 5.27 & 4.65 & 4.96 & 3.55 & 3.82 & 4.11 & 6.39 & 7.68 & 4.68 \\
\hline Cathepsin C & CTSC & Hs. 10029 & 5.00 & 4.53 & 3.07 & 2.46 & 6.92 & 4.52 & 7.05 & 6.78 & 6.75 & 2.92 \\
\hline Hypoxanthine phosphoribosyltransferase 1 & & & & & & & & & & & & \\
\hline (Lesch-Nyhan syndrome) & HPRT1 & Hs. 82314 & 4.95 & 5.13 & 2.72 & 3.79 & 2.94 & 3.16 & 8.76 & 8.08 & 6.23 & 3.71 \\
\hline Actin-related protein $2 / 3$ complex, subunit $1 \mathrm{~B}$, & & & & & & & & & & & & \\
\hline $41 \mathrm{kDa}$ & ARPC1B & Hs.433506 & 4.94 & 2.49 & 5.62 & 3.84 & 2.47 & 3.24 & 4.82 & 7.59 & 8.92 & 5.48 \\
\hline Annexin A4 & ANXA4 & Hs. 422986 & 4.92 & 1.70 & 10.68 & 5.50 & 1.09 & 4.99 & 9.05 & 5.36 & 3.63 & 2.27 \\
\hline Cofilin 1 (nonmuscle) & CFL1 & Hs. 180370 & 4.89 & 4.52 & 2.86 & 3.41 & 4.71 & 3.64 & 6.26 & 9.61 & 5.48 & 3.49 \\
\hline Chaperonin-containing TCP1, subunit $5(\varepsilon)$ & CCT5 & Hs. 1600 & 4.85 & 4.45 & 3.36 & 5.52 & 5.02 & 2.72 & 5.77 & 7.00 & 6.83 & 2.99 \\
\hline Ribosomal protein L3 & RPL3 & Hs. 119598 & 4.84 & 4.86 & 4.69 & 4.77 & 3.63 & 3.59 & 4.20 & 6.55 & 6.54 & 4.77 \\
\hline Rho GDP dissociation inhibitor (GDI) $\beta$ & ARHGDIB & Hs. 83656 & 4.81 & 5.40 & 2.16 & 4.60 & 3.70 & 6.08 & 5.75 & 5.90 & 5.88 & 3.82 \\
\hline
\end{tabular}


Table 1 (continued)

\begin{tabular}{|c|c|c|c|c|c|c|c|c|c|c|c|c|}
\hline Name & Symbol & Unigene ID & $\mathrm{MV} / \mathrm{hPDC}$ & BxPC-3 & AsPC-1 & Capan-1 & Capan-2 & HPAF2 & PI1 & PI3 & PI4 & PI5 \\
\hline Chromosome 15 open reading frame 15 & C15orf15 & Hs. 284162 & 4.81 & 4.61 & 2.24 & 6.37 & 2.59 & 4.94 & 7.03 & 4.59 & 4.61 & 6.31 \\
\hline unc- 84 homolog A (C. elegans) & UNC84A & Hs. 381143 & 4.76 & 5.66 & 5.57 & 4.02 & 3.36 & 3.86 & 5.99 & 4.03 & 4.87 & 5.48 \\
\hline Siah-interacting protein & SIP & Hs. 27258 & 4.73 & 2.65 & 3.26 & 2.76 & 4.49 & 3.88 & 7.11 & 7.59 & 6.68 & 4.17 \\
\hline Ribosomal protein, large, $\mathrm{P} 1$ & RPLP1 & Hs.424299 & 4.71 & 5.14 & 4.60 & 4.84 & 3.51 & 2.83 & 4.06 & 6.37 & 6.48 & 4.62 \\
\hline CGI-119 protein & CGI-119 & Hs. 283670 & 4.70 & 3.29 & 4.24 & 3.48 & 2.09 & 6.03 & 6.65 & 6.33 & 5.45 & 4.70 \\
\hline Programmed cell death 10 & PDCD10 & Hs. 28866 & 4.53 & 2.96 & 2.32 & 5.44 & 3.86 & 4.32 & 6.17 & 5.84 & 4.67 & 5.15 \\
\hline Adducin $3(\gamma)$ & ADD3 & Hs. 324470 & 4.46 & 3.95 & 7.51 & 4.35 & 3.07 & 4.37 & 6.95 & 3.51 & 3.68 & 2.77 \\
\hline \multicolumn{13}{|l|}{ Actin-related protein $2 / 3$ complex, subunit 5 , } \\
\hline $16 \mathrm{kDa}$ & ARPC5 & Hs. 82425 & 4.42 & 3.77 & 2.89 & 3.54 & 3.75 & 2.64 & 5.70 & 7.60 & 5.97 & 3.97 \\
\hline Ribosomal protein $\mathrm{S} 13$ & RPS13 & Hs. 165590 & 4.42 & 4.12 & 4.18 & 4.16 & 3.18 & 3.27 & 3.68 & 5.80 & 7.21 & 4.19 \\
\hline Family with sequence similarity 3 , member $\mathrm{C}$ & FAM3C & Hs.29882 & 4.33 & 2.94 & 2.60 & 3.84 & 5.91 & 3.09 & 6.01 & 4.39 & 4.44 & 5.77 \\
\hline $\begin{array}{l}\text { Eukaryotic translation initiation factor } 3 \\
\text { subunit } 5 \varepsilon, 47 \mathrm{kDa}\end{array}$ & \multicolumn{11}{|c|}{ Eukaryotic translation initiation factor 3} & 4.73 \\
\hline \multicolumn{13}{|l|}{ Protein phosphatase 2 (formerly $2 \mathrm{~A}$ ), catalytic } \\
\hline \multicolumn{13}{|l|}{ HMT1 hnRNP methyltransferase-like 2} \\
\hline (S. cerevisiae) & HRMT1L2 & Hs. 20521 & 4.23 & 4.56 & 3.58 & 3.76 & 3.36 & 3.78 & 3.33 & 5.91 & 5.11 & 4.63 \\
\hline Prohibitin & PHB & Hs. 75323 & 4.20 & 2.42 & 2.66 & 6.85 & 2.70 & 4.05 & 4.91 & 6.41 & 5.45 & 2.36 \\
\hline Chaperonin-containing TCP1, subunit $8(\theta)$ & CCT8 & Hs. 15071 & 4.15 & 3.00 & 4.41 & 2.57 & 4.72 & 3.59 & 6.80 & 4.29 & 4.21 & 3.74 \\
\hline Immediate early response 3 & IER3 & Hs. 76095 & 4.14 & 1.95 & 2.29 & 2.36 & 2.03 & 2.23 & 5.25 & 7.53 & 6.24 & 7.42 \\
\hline Peroxiredoxin 4 & PRDX4 & Hs. 83383 & 4.10 & 3.26 & 5.38 & 3.07 & 4.51 & 3.53 & 5.58 & 5.25 & 3.84 & 2.43 \\
\hline Sapiens cDNA: FLJ23477 fis, clone HSI 15732 & - & Hs. 145362 & 4.07 & 5.20 & 3.64 & 2.55 & 2.87 & 3.79 & 3.93 & 5.78 & 5.26 & 3.57 \\
\hline Heterogeneous nuclear ribonucleoprotein $\mathrm{K}$ & HNRPK & Hs. 129548 & 4.06 & 2.55 & 3.70 & 3.81 & 3.83 & 3.12 & 5.42 & 5.42 & 4.40 & 4.33 \\
\hline \multicolumn{13}{|l|}{ MCM7 minichromosome maintenance } \\
\hline deficient 7 (S. cerevisiae) & MCM7 & Hs. 77152 & 4.03 & 4.32 & 2.58 & 5.79 & 3.69 & 3.74 & 4.72 & 4.96 & 4.27 & 2.20 \\
\hline & - & EST & 3.95 & 4.04 & 4.16 & 2.30 & 3.12 & 2.75 & 3.64 & 5.69 & 5.69 & 4.15 \\
\hline \multicolumn{13}{|l|}{ Membranecofactor protein (CD46, trophoblast- } \\
\hline lymphocyte cross-reactive antigen) & $\mathrm{MCP}$ & Hs. 83532 & 3.94 & 4.10 & 3.10 & 3.85 & 4.53 & 4.52 & 5.34 & 3.85 & 2.85 & 3.33 \\
\hline Mitochondrial ribosomal protein L42 & MRPL42 & Hs. 112110 & 3.91 & 3.17 & 1.89 & 4.70 & 2.65 & 3.19 & 5.42 & 6.00 & 4.18 & 3.95 \\
\hline Heat shock $70 \mathrm{kDa}$ protein 8 & HSPA8 & Hs. 180414 & 3.90 & 3.46 & 4.79 & 2.91 & 3.39 & 3.71 & 4.34 & 4.66 & 3.40 & 4.46 \\
\hline \multicolumn{13}{|l|}{ NADH dehydrogenase (ubiquinone) } \\
\hline $1 \beta$ subcomplex, $9,22 \mathrm{kDa}$ & NDUFB9 & Hs. 15977 & 3.89 & 2.62 & 2.74 & 4.36 & 2.91 & 2.76 & 5.23 & 5.56 & 5.12 & 3.70 \\
\hline Ribosomal protein L7 & RPL7 & Hs. 153 & 3.85 & 2.22 & 3.56 & 3.62 & 3.15 & 3.35 & 3.66 & 5.57 & 5.46 & 4.10 \\
\hline Dynein, cytoplasmic, light polypeptide $2 \mathrm{~A}$ & DNCL2A & Hs. 100002 & 3.77 & 2.36 & 4.93 & 2.56 & 4.09 & 2.96 & 2.95 & 4.57 & 4.03 & 5.51 \\
\hline Matrin 3 & MATR3 & Hs.78825 & 3.76 & 2.79 & 3.79 & 2.57 & 2.90 & 3.21 & 5.08 & 5.33 & 4.36 & 3.82 \\
\hline Lysosomal-associated protein transmembrane $4 \alpha$ & LAPTM4A & Hs. 111894 & 3.74 & 2.50 & 6.00 & 3.71 & 3.11 & 3.68 & 4.36 & 3.58 & 2.94 & 3.83 \\
\hline KIAA0152 gene product & KIAA0152 & Hs. 181418 & 3.73 & 3.18 & 4.21 & 3.72 & 2.47 & 2.43 & 5.42 & 5.34 & 4.46 & 2.34 \\
\hline \multicolumn{13}{|l|}{ BUB3 budding uninhibited by benzimidazoles } \\
\hline 3 homolog (yeast) & BUB3 & Hs. 40323 & 3.72 & 3.45 & 1.81 & 2.30 & 4.02 & 4.06 & 5.36 & 5.85 & 4.28 & 2.34 \\
\hline Tubulin-specific chaperone a & TBCA & Hs. 433254 & 3.71 & 1.81 & 2.84 & 2.14 & 2.40 & 2.54 & 6.13 & 5.76 & 5.90 & 3.83 \\
\hline \multicolumn{13}{|l|}{ Ras-related $\mathrm{C} 3$ botulinum toxin substrate 1} \\
\hline (rho family, small GTP-binding protein Rac1) & $\mathrm{RAC1}$ & Hs. 173737 & 3.67 & 2.20 & 3.04 & 1.96 & 2.76 & 1.90 & 4.90 & 5.30 & 5.16 & 5.76 \\
\hline TERA protein & TERA & Hs. 180780 & 3.66 & 2.14 & 2.97 & 1.48 & 2.26 & 3.02 & 5.27 & 5.54 & 4.90 & 5.33 \\
\hline $\begin{array}{l}\text { Farnesyl diphosphate synthase (farnesyl } \\
\text { pyrophosphate synthetase, dimethylallyl- }\end{array}$ & & & & & & & & & & & & \\
\hline transtransferase, geranyltranstransferase) & FDPS & Hs. 335918 & 3.65 & 3.54 & 2.24 & 4.30 & 6.03 & 4.63 & 3.73 & 2.61 & 3.00 & 2.74 \\
\hline Poly $(\mathrm{rC})$-binding protein 2 & PCBP2 & Hs. 63525 & 3.64 & 3.72 & 3.35 & 2.38 & 3.78 & 4.39 & 3.71 & 4.43 & 3.51 & 3.46 \\
\hline Cytochrome $\mathrm{C}$ oxidase subunit VIc & COX6C & Hs. 351875 & 3.59 & 3.35 & 2.74 & 2.29 & 3.49 & 3.27 & 4.71 & 5.28 & 4.39 & 2.84 \\
\hline APEX nuclease (multifunctional DNA repair & & & & & & & & & & & & \\
\hline enzyme) 1 & APEX1 & Hs.73722 & 3.59 & 2.45 & 2.12 & 2.46 & 3.08 & 3.70 & 4.68 & 5.45 & 4.77 & 3.56 \\
\hline ATPase, $\mathrm{H}+$ transporting, lysosomal $21 \mathrm{kDa}, \mathrm{V} 0$ & & & & & & & & & & & & \\
\hline subunit c & ATP6V0B & Hs.7476 & 3.57 & 3.59 & 2.85 & 5.19 & 5.20 & 3.01 & 2.73 & 4.10 & 2.70 & 2.76 \\
\hline & & EST & 3.57 & 0.00 & 1.52 & 0.00 & 3.15 & 5.51 & 6.73 & 4.52 & 4.95 & 5.73 \\
\hline Hypothetical protein MGC14151 & MGC14151 & Hs. 333414 & 3.54 & 2.67 & 2.53 & 4.19 & 3.22 & 4.41 & 3.97 & 4.79 & 4.51 & 1.59 \\
\hline Cathepsin B & CTSB & Hs.297939 & 3.53 & 2.61 & 5.75 & 1.95 & 2.83 & 2.87 & 3.28 & 4.19 & 3.80 & 4.50 \\
\hline Prostatic-binding protein & PBP & Hs. 80423 & 3.52 & 2.79 & 3.35 & 2.71 & 2.12 & 3.20 & 4.40 & 6.36 & 4.17 & 2.57 \\
\hline Stathmin 1/oncoprotein 18 & STMN1 & Hs.406269 & 3.51 & 2.19 & 3.72 & 2.57 & 2.60 & 1.66 & 3.58 & 6.87 & 6.03 & 2.38 \\
\hline Activated RNA polymerase II transcription & & & & & & & & & & & & \\
\hline cofactor 4 & $\mathrm{PC} 4$ & Hs. 349506 & 3.50 & 2.76 & 1.81 & 3.25 & 2.41 & 3.60 & 4.04 & 5.67 & 4.30 & 3.69 \\
\hline NADH dehydrogenase (ubiquinone) & & & & & & & & & & & & \\
\hline $1 \beta$ subcomplex, $4,15 \mathrm{kDa}$ & NDUFB4 & Hs. 227750 & 3.50 & 3.24 & 2.62 & 3.05 & 3.98 & 3.98 & 4.11 & 4.17 & 3.43 & 2.93 \\
\hline Uncharacterized hypothalamus protein & & & & & & & & & & & & \\
\hline НT007 & НТ007 & Hs. 24371 & 3.50 & 3.47 & 1.65 & 3.87 & 2.82 & 3.08 & 4.95 & 4.24 & 4.09 & 3.33 \\
\hline $\begin{array}{l}\text { Proteasome (prosome. macropain) subunit, } \\
\quad \alpha \text { type, } 6\end{array}$ & PSMA6 & Hs.410276 & 3.50 & 3.66 & 2.30 & 4.30 & 1.58 & 2.97 & 3.56 & 5.09 & 5.14 & 2.87 \\
\hline ATPsynthase, $\mathrm{H}+$ transporting, mitochondrial & & & & & & & & & & & & \\
\hline F0 complex, subunit d & АТP5H & Hs. 49018 & 3.46 & 2.15 & 2.13 & 1.96 & 3.15 & 3.32 & 5.50 & 5.35 & 4.39 & 3.17 \\
\hline Barrier to autointegration factor 1 & BANF1 & Hs.433759 & 3.44 & 3.93 & 2.13 & 2.66 & 2.62 & 3.24 & 4.55 & 5.77 & 3.18 & 2.91 \\
\hline Stearoyl-CoA desaturase ( $\delta$-9-desaturase) & SCD & Hs. 119597 & 3.44 & 5.59 & 2.76 & 3.28 & 3.96 & 2.82 & 3.84 & 3.19 & 3.00 & 2.51 \\
\hline Chaperonin-containing TCP1, subunit $6 \mathrm{~A}(\zeta)$ & ССТ6А & Hs. 82916 & 3.42 & 2.73 & 2.40 & 3.11 & 2.81 & 2.36 & 4.46 & 4.98 & 4.11 & 3.77 \\
\hline
\end{tabular}


Table 1 (continued)

\begin{tabular}{|c|c|c|c|c|c|c|c|c|c|c|c|c|}
\hline Name & Symbol & Unigene ID & $\mathrm{MV} / \mathrm{hPDC}$ & BxPC-3 & AsPC-1 & Capan-1 & Capan-2 & HPAF2 & PI1 & PI3 & PI4 & PI5 \\
\hline Interferon, $\alpha$-inducible protein (clone IFI-15K) & G1P2 & Hs. 432233 & 3.41 & 2.95 & 4.58 & 3.91 & 5.27 & 3.73 & 2.29 & 3.22 & 2.57 & 2.15 \\
\hline Peroxiredoxin 5 & PRDX 5 & Hs. 31731 & 3.39 & 3.36 & 2.17 & 2.47 & 2.33 & 2.85 & 3.89 & 5.17 & 4.12 & 4.12 \\
\hline \multicolumn{13}{|l|}{ ATPsynthase, $\mathrm{H}+$ transporting, mitochondrial } \\
\hline F0 complex, subunit $\mathrm{f}$, isoform 2 & ATP5J2 & Hs. 235557 & 3.36 & 4.04 & 1.31 & 4.50 & 3.62 & 3.87 & 4.48 & 3.96 & 2.90 & 1.59 \\
\hline Ribosomal protein $\mathrm{S} 9$ & RPS9 & Hs. 180920 & 3.33 & 3.34 & 3.11 & 3.23 & 2.31 & 2.52 & 2.68 & 4.22 & 5.49 & 3.05 \\
\hline \multicolumn{13}{|l|}{$\begin{array}{l}\text { X-ray repair complementing defective repair } \\
\text { in Chinese hamster cells } 5 \text { (double-strand- }\end{array}$} \\
\hline break rejoining; Ku autoantigen, 80 kDa) & XRCC & Hs. 84981 & 3.29 & 1.88 & 2.91 & 2.26 & 3.00 & 2.26 & 5.36 & 5.03 & 3.90 & 3.02 \\
\hline Chromosome 20 open reading frame 43 & $\mathrm{C} 20$ orf 43 & Hs. 182281 & 3.29 & 3.69 & 3.15 & 2.99 & 3.03 & 2.89 & 3.08 & 4.21 & 3.15 & 3.43 \\
\hline \multicolumn{13}{|l|}{ Glioma tumor suppressor candidate region } \\
\hline gene 2 & GLTSCR2 & Hs. 421907 & 3.28 & 2.88 & 3.91 & 1.89 & 2.42 & 2.68 & 3.55 & 3.42 & 4.19 & 4.55 \\
\hline \multicolumn{13}{|l|}{ Small nuclear ribonucleoprotein } \\
\hline $\mathrm{D} 2$ polypeptide $16.5 \mathrm{kDa}$ & SNRPD2 & Hs. 424327 & 3.25 & 3.27 & 3.06 & 3.13 & 2.35 & 2.59 & 2.76 & 4.24 & 5.06 & 2.83 \\
\hline Defender against cell death 1 & DAD1 & Hs. 82890 & 3.24 & 3.09 & 2.87 & 2.70 & 3.13 & 3.59 & 3.98 & 3.95 & 2.59 & 3.30 \\
\hline Protein disulfide isomerase-related protein & P5 & Hs. 182429 & 3.24 & 1.98 & 3.73 & 2.83 & 2.80 & 3.16 & 4.71 & 4.27 & 3.04 & 2.67 \\
\hline Cell death-regulatory protein GRIM19 & GRIM19 & Hs. 279574 & 3.23 & 2.39 & 2.75 & 2.88 & 2.60 & 2.19 & 4.07 & 6.15 & 3.45 & 2.60 \\
\hline Death-associated protein 3 & DAP3 & Hs. 159627 & 3.17 & 2.19 & 1.52 & 2.54 & 2.98 & 2.54 & 3.42 & 5.04 & 4.62 & 3.71 \\
\hline Inorganic pyrophosphatase 2 & PPA2 & Hs. 5123 & 3.17 & 3.79 & 1.86 & 3.20 & 2.56 & 2.93 & 4.30 & 4.06 & 3.93 & 1.89 \\
\hline Poly(A)-binding protein, cytoplasmic 1 & PABPC1 & Hs. 172182 & 3.16 & 2.73 & 2.82 & 2.81 & 3.30 & 2.72 & 3.96 & 3.17 & 3.24 & 3.65 \\
\hline Ribosomal protein L13 & RPL13 & Hs. 431392 & 3.14 & 3.33 & 2.95 & 3.13 & 2.24 & 2.44 & 2.59 & 4.08 & 4.56 & 2.96 \\
\hline \multicolumn{13}{|l|}{ Guanine-nucleotide-binding protein } \\
\hline (G protein), $\gamma_{12}$ & GNG12 & Hs. 8107 & 3.13 & 2.81 & 3.22 & 2.23 & 2.40 & 3.71 & 4.11 & 3.53 & 3.32 & 2.84 \\
\hline \multicolumn{13}{|l|}{$\mathrm{CDC} 10$ cell division cycle 10 homolog } \\
\hline (S. cerevisiae) & $\mathrm{CDC} 10$ & Hs. 184326 & 3.10 & 2.68 & 2.38 & 1.95 & 2.42 & 2.45 & 4.84 & 4.53 & 3.85 & 2.82 \\
\hline Anaplastic lymphoma kinase (Ki-1) & ALK & Hs.9614 & 3.10 & 2.49 & 2.67 & 2.21 & 2.49 & 2.51 & 3.80 & 4.89 & 4.09 & 2.77 \\
\hline
\end{tabular}

B. Genes downregulated in tumor cell lines

\begin{tabular}{|c|c|c|c|c|c|c|c|c|c|c|c|c|}
\hline Name & Symbol & Unigene ID & $\mathrm{MV} / \mathrm{hPDC}$ & BxPC-3 & AsPC-1 & Capan-1 & Capan-2 & HPAF2 & PI1 & PI3 & PI4 & PI5 \\
\hline Thrombospondin 1 & THBS1 & Hs. 87409 & 0.31 & 0.60 & 0.10 & 0.13 & 0.52 & & 0.29 & 0.30 & 0.22 & 0.33 \\
\hline Leucine-rich repeat-containing 8 & LRRC8 & Hs. 173484 & 0.31 & 0.51 & 0.22 & & 0.48 & 0.20 & 0.24 & 0.25 & 0.29 & 0.29 \\
\hline Phosphoprotein enriched in astrocytes 15 & PEA15 & Hs.194673 & 0.29 & 0.24 & 0.19 & 0.26 & 0.32 & 0.21 & 0.21 & 0.38 & 0.40 & 0.40 \\
\hline $\begin{array}{l}\text { Coatomer protein complex, subunit } \alpha \\
\text { Sapiens cDNA FLJ } 11812 \text { fis, clone }\end{array}$ & COPA & Hs. 75887 & 0.29 & 0.25 & 0.25 & 0.32 & 0.24 & 0.30 & 0.32 & 0.32 & 0.31 & 0.31 \\
\hline HEMBA1006364 & & Hs. 23837 & 0.28 & 0.21 & & 0.28 & 0.49 & 0.29 & 0.21 & 0.26 & 0.28 & 0.21 \\
\hline Ets homologous factor & EHF & Hs. 182339 & 0.28 & 0.31 & 0.26 & 0.26 & 0.20 & 0.32 & 0.27 & 0.30 & 0.29 & 0.30 \\
\hline Dual specificity phosphatase 1 & DUSP1 & Hs. 171695 & 0.27 & 0.11 & 0.28 & 0.09 & 0.10 & 0.10 & 0.16 & 0.21 & 0.41 & 0.94 \\
\hline Tubulin, $\alpha_{3}$ & TUBA3 & Hs.433394 & 0.25 & & & 0.12 & 0.12 & & 0.10 & 0.35 & 0.37 & 0.42 \\
\hline Small nuclear ribonucleoprotein polypeptide $\mathrm{N}$ & SNRPN & Hs. 48375 & 0.24 & 0.22 & 0.12 & 0.50 & 0.33 & 0.13 & 0.15 & & & \\
\hline Zinc finger protein 217 & ZNF217 & Hs. 155040 & 0.23 & 0.24 & 0.24 & 0.24 & 0.14 & 0.20 & 0.24 & 0.25 & & 0.31 \\
\hline Hypothetical protein BM-002 & BM-002 & Hs. 367646 & 0.23 & 0.32 & 0.09 & 0.21 & 0.24 & 0.22 & & & & 0.29 \\
\hline $\begin{array}{l}\text { Amphiregulin (schwannoma-derived growth } \\
\text { factor) }\end{array}$ & AREG & Hs. 270833 & 0.20 & 0.24 & & 0.21 & 0.14 & 0.16 & 0.20 & & 0.18 & 0.24 \\
\hline Cyclin-dependent kinase inhibitor $1 \mathrm{~A}$ & & & & & & & & & & & & \\
\hline $\begin{array}{l}\quad(\mathrm{p} 21, \mathrm{Cip} 1) \\
\text { CCR4-NOT transcription complex, subunit } 7\end{array}$ & $\begin{array}{l}\text { CDKN1A } \\
\text { CNOT7 }\end{array}$ & $\begin{array}{l}\text { Hs. } 179665 \\
\text { Hs.380963 }\end{array}$ & $\begin{array}{l}0.17 \\
0.17\end{array}$ & $\begin{array}{l}0.16 \\
0.19\end{array}$ & $\begin{array}{l}0.12 \\
0.12\end{array}$ & $\begin{array}{l}0.14 \\
0.13\end{array}$ & $\begin{array}{l}0.14 \\
0.18\end{array}$ & $\begin{array}{l}0.10 \\
0.15\end{array}$ & $\begin{array}{l}0.08 \\
0.16\end{array}$ & $\begin{array}{l}0.19 \\
0.22\end{array}$ & $\begin{array}{l}0.21 \\
0.18\end{array}$ & $\begin{array}{l}0.39 \\
0.15\end{array}$ \\
\hline $\begin{array}{l}\text { Serine (or cysteine) proteinase inhibitor, } \\
\text { clade B (ovalbumin), member } 2\end{array}$ & SERPINB2 & Hs.75716 & 0.13 & 0.71 & 0.03 & & 0.03 & & 0.05 & 0.03 & 0.04 & 0.04 \\
\hline Serum amyloid A1 & SAA1 & Hs. 332053 & 0.12 & 0.10 & & 0.11 & 0.15 & & & & & \\
\hline Hypothetical protein FLJ10154 & FLJ10154 & Hs.179972 & 0.10 & 0.10 & 0.07 & 0.07 & 0.06 & 0.06 & 0.12 & 0.17 & 0.16 & 0.10 \\
\hline KIAA0669 gene product & KIAA0669 & Hs.52526 & 0.07 & & 0.04 & & 0.05 & 0.05 & 0.07 & 0.07 & 0.07 & 0.10 \\
\hline
\end{tabular}

C. Genes upregulated in primary isolates only

\begin{tabular}{|c|c|c|c|c|c|c|c|c|c|c|c|c|c|c|}
\hline Name & Symbol & Unigene ID & $\begin{array}{l}\text { MV } \\
\text { all/hPDC }\end{array}$ & $\begin{array}{l}\text { MV } \\
\text { ATCC/ } \\
\text { hPDC }\end{array}$ & $\begin{array}{l}\text { MV PI/ } \\
\text { hPDC }\end{array}$ & BxPC-3 & AsPC-1 & Capan-1 & Capan- & $2 \mathrm{HPAF}$ & PI1 & PI3 & PI4 & PI5 \\
\hline Importin 7 & IPO7 & Hs. 5151 & 2.31 & 1.51 & 3.11 & & 1.90 & 1.25 & 1.25 & 1.63 & 3.33 & 3.22 & 3.37 & 2.52 \\
\hline Hypothetical protein DKFZp434L142 & DKFZp434L142 & Hs.323583 & 2.23 & 0.95 & 3.52 & 0.81 & 0.95 & 1.16 & & 0.87 & 4.94 & 4.68 & 3.37 & 1.08 \\
\hline Transmembrane 4 superfamily member 7 & TM4SF7 & Hs. 26518 & 3.12 & 1.90 & 4.03 & 1.86 & 2.07 & & & 1.76 & 2.31 & 5.57 & 4.04 & 4.20 \\
\hline Insulin-like-growth-factor-binding protein 6 & IGFBP6 & Hs. 274313 & 3.34 & 2.18 & 4.50 & 5.89 & & 0.87 & 0.81 & 1.15 & 5.44 & 4.80 & 3.74 & 4.02 \\
\hline Chromosome 8 open reading frame 4 & C8orf4 & Hs. 283683 & 3.32 & 0.88 & 4.53 & 0.43 & & 1.34 & & & 1.07 & 2.96 & 3.62 & 10.49 \\
\hline Insulin-like-growth-factor-binding protein 3 & IGFBP3 & Hs.77326 & 5.29 & 1.68 & 8.89 & & 2.87 & 1.93 & 1.08 & 0.84 & 6.25 & 9.80 & 12.39 & 7.12 \\
\hline Vimentin & VIM & Hs. 297753 & 5.21 & 1.25 & 9.17 & 0.34 & 3.70 & & 0.63 & 0.34 & 6.60 & 10.34 & 12.25 & 7.51 \\
\hline
\end{tabular}

$\overline{\text { Gene Expression Analysis of Pancreatic Cell }}$ 
Table 1 (continued)

D. Genes downregulated in primary isolates only

\begin{tabular}{|c|c|c|c|c|c|c|c|c|c|c|c|c|c|c|}
\hline Name & Symbol & Unigene ID & $\begin{array}{l}\text { MV all/ } \\
\text { hPDC }\end{array}$ & $\begin{array}{l}\text { MV } \\
\text { ATCC/ } \\
\text { hPDC }\end{array}$ & $\begin{array}{l}\text { MV PI/ } \\
\text { hPDC }\end{array}$ & BxPC-3 & AsPC-1 & Capan-1 & Capan-2 & 2 HPAF2 & PI1 & PI3 & PI4 & PI5 \\
\hline CD24 antigen & $\mathrm{CD} 24$ & Hs. 375108 & 0.41 & 0.59 & 0.03 & 0.70 & 0.38 & 0.89 & & 0.40 & 0.03 & 0.03 & 0.02 & \\
\hline \multicolumn{15}{|l|}{ Secretory leukocyte protease } \\
\hline Inhibitor (antileukoproteinase) & SLPI & Hs. 251754 & 0.56 & 0.79 & 0.28 & 0.79 & 0.94 & 1.07 & 0.41 & 0.71 & 0.56 & 0.15 & 0.13 & 0.27 \\
\hline Cadherin 1, E-cadherin & CDH1 & Hs. 194657 & 0.58 & 0.83 & 0.28 & 1.11 & 0.65 & 1.00 & 0.79 & 0.59 & 0.49 & 0.17 & 0.20 & 0.25 \\
\hline
\end{tabular}

E. Genes upregulated in ATCC cell lines only

\begin{tabular}{lcccccccccccccccc}
\hline Name & Symbol & Unigene ID & $\begin{array}{l}\text { MV all/ } \\
\text { hPDC }\end{array}$ & $\begin{array}{l}\text { MV } \\
\text { ATCC/ } \\
\text { hPDC }\end{array}$ & $\begin{array}{l}\text { MV PI/ } \\
\text { hPDC }\end{array}$ & BxPC-3 & AsPC-1 & Capan-1 Capan-2 HPAF2 PI1 PI3 PI4 PI5 \\
\hline Frizzled 6 & FZD6 & Hs.114218 & 3.12 & 3.55 & 1.25 & 6.62 & 3.97 & 3.90 & 3.88 & 3.75 & 1.64 & 0.87 & 1.11 & 1.37 \\
\hline
\end{tabular}

The fold change of expression of the tumor cell lines vs. the cell line hPDC. MV/hPDC = fold change of the mean of the expression value of the tumor cell lines vs. hPDC.

Fig. 2. Functional categories of differentially expressed genes. Numbers above the bars indicate the number of genes within the group.

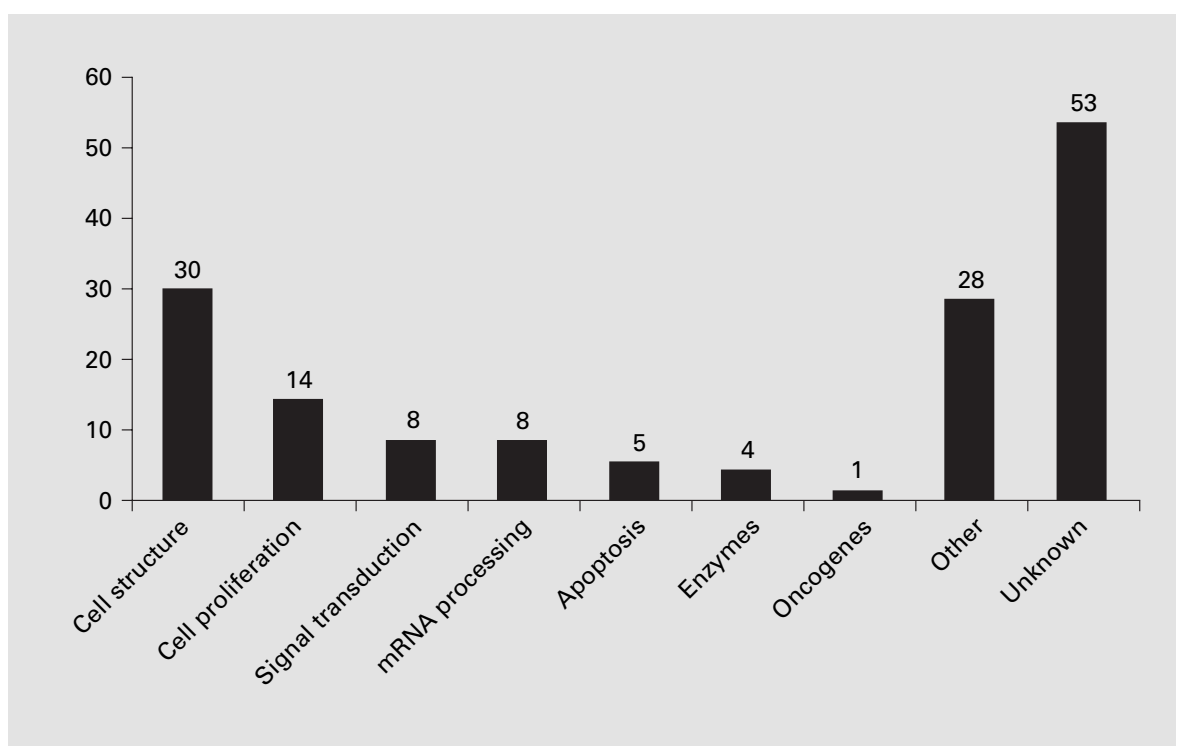

\section{Overexpression of TMSB10 in Human Pancreatic}

\section{Carcinoma}

Expression changes observed in cell lines are not necessarily represented in primary tissues also. Therefore, out of the 122 upregulated genes we selected TMSB10 to analyze the expression of its protein in human pancreatic adenocarcinoma by using a polyclonal antibody and immunohistochemistry. Moreover, TMSB10 is associated with cellular proliferation in a number of cancers indicating that overexpression of this gene might be a causal event [13].
TMSB10 expression was detected in endothelium, smooth muscle cells, neuronal cells, and strongly in macrophages, both in tumor and in normal tissues. In 49 of the $54(90.7 \%)$ ductal adenocarcinomas examined, immunoreactivity for TMSB10 was detected in the tumor cells (fig. 3). Conversely, in none of the 10 sections of normal pancreatic tissue could TMSB10 be shown by means of immunohistochemistry. In 24 of $54(44.4 \%)$ cases, we detected staining in the stroma. The correlation between staining in the tumor and staining in stroma cells, which 

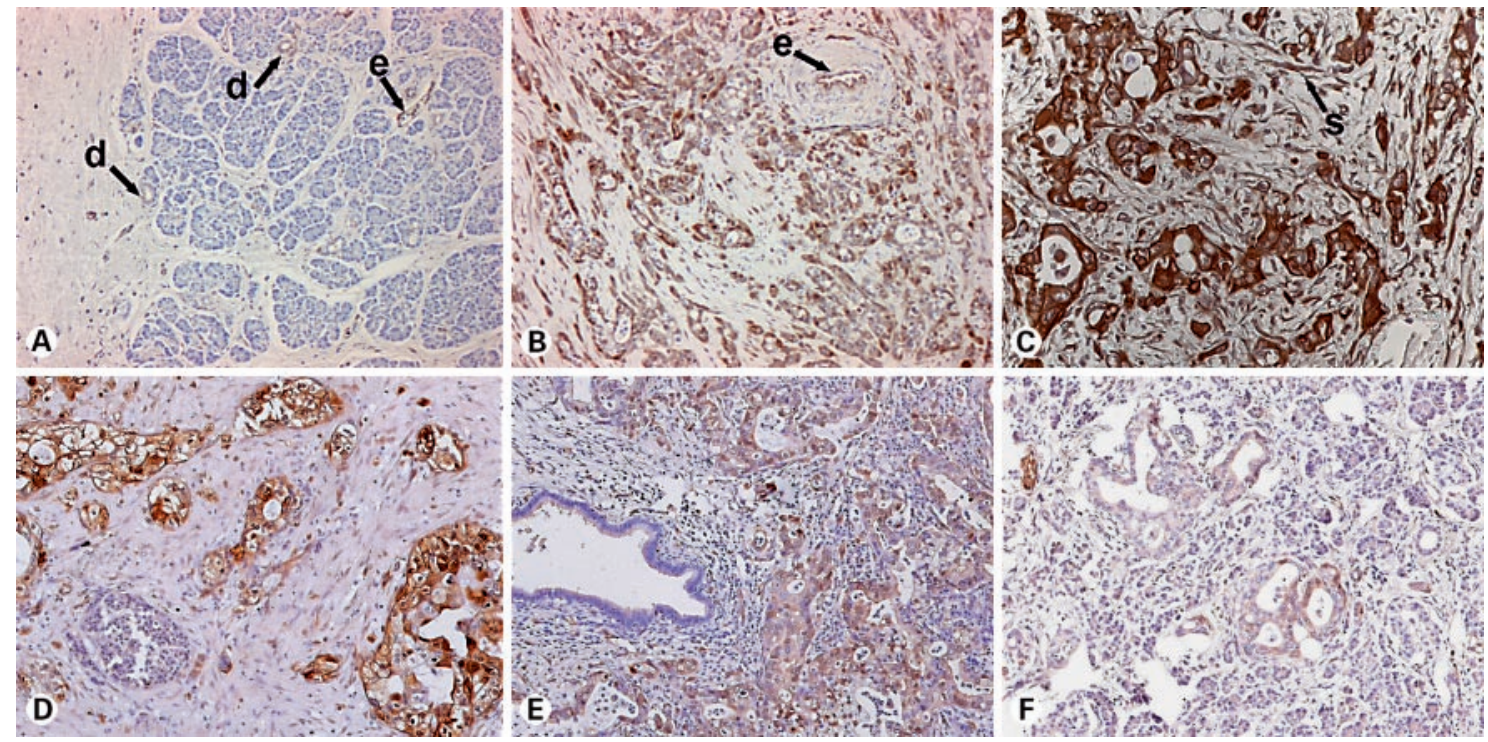

Fig. 3. Immunohistochemical staining of non-neoplastic pancreas (A), ductal pancreatic adenocarcinoma (B) and stromal tissue within a pancreatic adenocarcinoma (C) using TMSB10 antibody. Examples for normal ducts (d), endothelial cells (e) and stromal cells (s) are indicated with arrows. The pancreatic adenocarcinoma $\mathbf{B}$ was scored as $2+$ and the sample C as $3+$. A, B $100 \times$, C $200 \times$ magnification. D-F Strong (D), moderate $(\mathbf{E})$ and weak (F) staining of pancreatic adenocarcinoma samples.

Table 2. Genes known to be involved in tumorigenesis in various tissues

\begin{tabular}{|c|c|c|c|c|c|c|}
\hline Name & Symbol & Unigene ID & Function & $\begin{array}{l}\text { Involved } \\
\text { in cancer }\end{array}$ & $\begin{array}{l}\text { Involved in } \\
\text { pancreatic } \\
\text { cancer }\end{array}$ & Reference \\
\hline Prefoldin 5 & PFDN5 & Hs. 288856 & Chaperone & & Yes & {$[25]$} \\
\hline Thymosin $\beta-10$ & TMSB 10 & Hs.76293 & Proliferation & Yes & & {$[13,22,23]$} \\
\hline Calmodulin 1 & CALM1 & Hs.374441 & Signal transduction & Yes & No & [26] \\
\hline \multicolumn{7}{|l|}{ Cellular apoptosis susceptibility } \\
\hline protein CSE1L/CAS & CSE1L & Hs. 90073 & Proliferation and apoptosis & Yes & No & {$[27]$} \\
\hline Lymphocyte antigen 6 & LY6E & Hs. 77667 & Signal transduction & Yes & No & [28] \\
\hline Cyclin-dependent kinase 4 & CDK4 & Hs. 95577 & Cell cycle & Yes & No & [29] \\
\hline ADAM9 & ADAM9 & Hs. 2442 & Proliferation & Yes & Yes & [30] \\
\hline Prohibitin & PHB & Hs.75323 & Proliferation & Yes & No & {$[31]$} \\
\hline Cyclin-dependent kinase inhibitor 1 & CDKN1A & Hs. 179665 & Apoptosis & Yes & No & [32] \\
\hline E-cadherin & $\mathrm{CDH} 1$ & Hs. 194657 & Cell adhesion & Yes & Yes & {$[16,18,33,34]$} \\
\hline
\end{tabular}

Table 3. TMSB10 protein expression in pancreatic ductal adenocarcinoma cells $(n=55)$ and in stroma cells within the tumors

\begin{tabular}{lll}
\hline & Tumor positive & Tumor negative \\
\hline Stroma positive & 20 & 2 \\
Stroma negative & 28 & 5
\end{tabular}

$\mathrm{p}=0.411$, Fisher's exact test.

Gene Expression Analysis of Pancreatic Cell Lines was not significant, is shown in table 3. Furthermore, we could not find a significant correlation between the positivity or the intensity of expression of TMSB10 and postoperative survival of patients. However, we observed that TMSB10 is highly expressed within well- and poorly-differentiated carcinomas (G1 and G3), whereas the majority of moderately differentiated tumors (G2) expressed TMSB 10 only moderately.

Pancreatology 2005;5:370-379 


\section{Discussion}

The DNA microarray technology is widely used as a powerful tool to investigate the mRNA expression pattern of various tissues and cell types. For tissues that are difficult to access or scarcely available, cell lines are a helpful alternative. This is especially true for pancreatic cancer. It is well known that cells change both their morphology and their expression pattern when isolated from their parent organism, the human body $[14,15]$. However, analysis of cell lines might circumvent the need for microdissection of tissues and, furthermore, allow the characterization of the most adequate model system for further analysis of differentially expressed genes.

Upregulation of growth factors, cytokines, receptors, extracellular matrix proteins and numerous other proteins is a common event in carcinogenesis. We corroborated this in the pancreatic tumor cell lines analyzed in this study, finding 122 genes upregulated and only 18 downregulated in respect to benign cells.

Apart from the genes differentially regulated in all cell lines, we found 7 genes upregulated and 3 genes downregulated in the primary isolates only, while 1 gene, frizzled 6, was upregulated only in the ATCC cell lines. E-cadherin, 1 of the 3 genes downregulated in primary cells, is the main adhesion molecule of epithelia, and it has been implicated in carcinogenesis because it is frequently lost in human epithelial cancers [16]. It is known to act as a strong invasion suppressor in experimental tumor cell systems [17]. Partial or complete loss of E-cadherin expression correlates with malignancy in human cancers [18]. Interestingly, we found downregulation in the primary isolates, but not in the ATCC cells, which may support the assumption that primary cell lines reflect the biological features of the tumor more than established cell lines.

The mesenchymal intermediate filament marker vimentin is strongly expressed in invasive pancreatic carcinomas [19] and generally expressed in pancreatic carcinoma cell lines [20]. The overexpression in primary isolates suggests a relative importance of this filament in cells adapting to the new environment petridish; it seems to be of less importance after adjustment to the different needs of the cells in vitro. Most genes, however, show a comparable degree of expression. This might support the assumption that cells adapt very quickly when isolated and transferred into medium. If they would not, they could not replicate and survive. Within the large set of genes implied in cellular proliferation and identified by the GeneChip analysis we were especially interested in the analysis of TMSB10. The $\beta$-thymosins are a family of related peptides known to be present in a wide variety of mammalian and other vertebrate cells and tissues. TMSB10 mRNA is overexpressed in germ cell tumors of different histological types, breast-, ovarian-, uterine carcinomas, colon, thyroid and esophageal carcinoma cell lines [13, 21, 22]. It has also been shown that TMSB10 plays a critical role in the regulation of anchorage-independent growth and assembly of actin filaments [23]. Furthermore upregulation of TMSB10 was identified in the breast cancer cell line MCF-7 in the course of treatment with 5-fluorouracil, tomudex and oxaliplatin, respectively. TMSB 10 expression is also elevated in the 5-fluorouracil-resistant colon cancer cell line H630R10 [24] implying a role for TMSB10 within the reaction of cells on toxic compounds.

In conclusion we have reported for the first time the expression of TMSB10 in pancreatic carcinoma. TMSB10 might play a general role in human carcinogenesis and in pancreatic carcinomas especially. Our finding that TMSB10 is strongly expressed in stroma cells of pancreatic carcinoma supports the suggestion of Santelli et al. [23] who claim a critical role for TMSB10 in the regulation of anchorage-independent growth and assembly of actin filaments.

\section{Acknowledgments}

Thanks to Alfred E. Neuman whose comments were always appreciated and to Marit Biesold for technical assistance. This manuscript was supported by the Deutsche Krebshilfe (70-2937-SaI). The data set of this study can be obtained from http://vtg.uniklinikum-dresden.de/pankreaslabor. 


\section{References}

1 Jemal A, Murray T, Samuels A, Ghafoor A Ward E, Thun MJ: Cancer statistics. CA Cancer J Clin 2003;53:5-26.

2 Arbeitsgemeinschaft Bevölkerungsbezogener Krebsregister in Deutschland: Häufigkeiten und Trends. In Zusammenarbeit mit dem Robert Koch Institut. Saarbrücken, 1999.

3 Friess H, Ding J, Kleeff J, Liao Q, Berberat PO, Hammer J, Büchler MW: Identification of disease-specific genes in chronic pancreatitis using DNA array technology. Ann Surg 2002;234 769-779.

4 van Hal NL, Vorst O, van Houwelingen AM, Kok EJ, Peijnenburg A, Aharoni A, van Tunen AJ, Keijer J: The application of DNA microarrays in gene expression analysis. J Biotechno 2000;78:271-280

5 Han H, Bearss DJ, Browne LW, Calaluce R, Nagle RB, Hoff DDV: Identification of differentially expressed genes in pancreatic cancer cells using cDNA microarray. Cancer Res 2002;62:2890-2896

6 Iacobuzio-Donahue CA, Maitra A, Shen-Ong GL, van Heek T, Ashfaq R, Meyer R, Walter K, Berg K, Hollingsworth MA, Cameron JL, Yeo CJ, Kern SE, Goggins M, Hruban RH Discovery of novel tumor markers of pancreatic cancer using global gene expression technology. Am J Pathol 2002;160:1239-1249.

7 Iacobuzio-Donahue CA, Maitra A, Olsen M, Lowe AW, van Heek NT, Rosty C, Walter K, Sato N, Parker A, Ashfaq R, Jaffee E, Ryu B, Jones J, Eshleman JR, Yeo CJ, Cameron JL, Kern SE, Hruban RH, Brown PO, Goggins M: Exploration of global gene expression patterns in pancreatic adenocarcinoma using cDNA microarrays. Am J Pathol 2003;162:1151-1162.

8 Peiper M, Alldinger I, Heller R, Pilarsky C, Schumacher U, Knoefel WT, Heinecke A, Izbicki JR: Biological and molecular characterization of a new human ampullary cancer cell line. Anticancer Res 2003;23:291-298

9 Jesnowski R, Muller P, Schareck W, Liebe S, Löhr M: Immortalized pancreatic duct cells in vitro and in vivo. Ann NY Acad Sci 1999;880 50-65.

10 Grutzmann R, Pilarsky C, Staub E, Schmitt A Foerder M, Specht T, Hinzmann B, Dahl E, Alldinger I, Rosenthal A, Ockert D, Saeger H: Systematic isolation of genes differentially expressed in normal and cancerous tissue of the pancreas. Pancreatology 2003;3:169-178.

11 Schmitt AO, Specht T, Beckmann G, Dahl E, Pilarsky CP, Hinzmann B, Rosenthal A: Exhaustive mining of EST libraries for genes differentially expressed in normal and tumour tissues. Nucleic Acids Res 1999;27:4251-4260.

12 Irizarry RA, Bolstad BM, Collin F, Cope LM, Hobbs B, Speed TP: Summaries of Affymetrix GeneChip probe level data. Nucleic Acids Res 2003;31:e15.
13 Santelli G, Califano D, Chiappetta G, Vento M, Bartoli P, Zullo F, Trapasso F, Viglietto G, Fusco A: Thymosin beta-10 gene overexpression is a general event in human carcinogenesis. Am J Pathol 1999; 155:799-804.

14 Ghadimi BM, Schröck E, Walker RL, Wangsa D, Jauho A, Meltzer PS, Ried T: Specific chromosomal aberration and amplification of the AIB1 nuclear receptor coactivator gene in pancreatic carcinomas. Am J Pathol 1999;154: 525-536.

15 Grutzmann R, Foerder M, Alldinger I, Staub E, Brummendorf T, Ropcke S, Li X, Kristiansen G, Jesnowski R, Sipos B, Löhr M, Luttges J, Ockert D, Kloppel G, Saeger HD, Pilarsky C: Gene expression profiles of microdissected pancreatic ductal adenocarcinoma. Virchows Arch 2003;443:508-517

16 Perl AK, Wilgenbus P, Dahl U, Semb H, Christofori G: A causal role for E-cadherin in the transition from adenoma to carcinoma. Nature 1998;392:190-193.

17 Berx G, Becker KF, Hofler H, van Roy F: Mutations of the human E-cadherin (CDH1) gene. Hum Mutat 1998;12:226-237.

18 Berx G, Cleton-Jansen AM, Nollet F, de Leeuw WJ, van de Vijver M, Cornelisse C, van Roy F: E-cadherin is a tumour/invasion suppressor gene mutated in human lobular breast cancers. EMBO J 1995;14:6107-6115.

19 Buchholz M, Biebl A, Neebetae A, Wagner M, Iwamura T, Leder G, Adler G, Gress TM: SERPINE2 (protease nexin I) promotes extracellular matrix production and local invasion of pancreatic tumors in vivo. Cancer Res 2003; 63:4945-4951.

20 Sipos B, Moser S, Kalthoff H, Torok V, Löhr M, Kloppel G: A comprehensive characterization of pancreatic ductal carcinoma cell lines: Towards the establishment of an in vitro research platform. Virchows Arch 2003;442: 444-452.

21 Viglietto $G$, Califano D, Bruni P, Baldassarre G, Vento MT, Belletti B, Fedele M, Santelli G, Boccia A, Manzo G, Santoro M, Fusco A: Regulation of thymosin beta 10 expression by TSH and other mitogenic signals in the thyroid gland and in cultured thyrocytes. Eur J Endocrinol 1999;140:597-607.

22 Lee SH, Zhang W, Choi JJ, Cho YS, Lee SH, Kim JW, Hu L, Xu J, Liu J, Lee JH: Overexpression of the thymosin beta-10 gene in human ovarian cancer cells disrupts F-actin stress fiber and leads to apoptosis. Oncogene 2001; 20:6700-6706.

23 Santelli G, Bartoli PC, Giuliano A, Porcellini A, Mineo A, Barone MV, Busiello I, Trapasso F, Califano D, Fusco A: Thymosin beta-10 protein synthesis suppression reduces the growth of human thyroid carcinoma cells in semisolid medium. Thyroid 2002;12:765-772.
24 Maxwell PJ, Longley DB, Latif T, Boyer J, Allen W, Lynch M, McDermott U, Harkin DP, Allegra CJ, Johnston PG: Identification of 5fluorouracil-inducible target genes using cDNA microarray profiling. Cancer Res 2003;63: 4602-4606.

25 Ampe C, Vandekerckhove J, Klein HL, Cowan NJ: Prefoldin, a chaperone that delivers unfolded proteins to cytosolic chaperonin. Cell Calcium 1998;93:863-873.

26 Toutenhoofd SL, Strehler EE: Regulation of calmodulin mRNAs in differentiating human IMR-32 neuroblastoma cells. Biochim Biophys Acta 2002;1600:95-104.

27 Behrens P, Brinkmann U, Wellmann A: CSE1L/CAS: Its role in proliferation and apoptosis. Apoptosis 2003;8:39-44.

28 Witz IP: Differential expression of genes by tumor cells of a low or a high malignancy phenotype: The case of murine and human Ly-6 proteins. J Cell Biochem Suppl 2000;34:6166

29 Wolfel T, Hauer M, Schneider J, Serrano M, Wolfel C, Klehmann-Hieb E, De Plaen E, Hankeln T, Meyer zum Buschenfelde KH, Beach D: A p16INK4a-insensitive CDK4 mutant targeted by cytolytic T lymphocytes in a human melanoma. Science 1995;269:1281-1284.

30 Grutzmann R, Lüttges J, Sipos B, Dobrowolski F, Alldinger I, Kersting S, Ockert D, Koch R, Kalthoff H, Schackert HK, Kremer B, Saeger HD, Klöppel G, Pilarsky C: ADAM9 is a independent prognostic parameter of pancreatic ductal adenocarcinoma survival. Br J Cancer 2004;90:1053-1058.

31 Sato T, Saito H, Swensen J, Olifant A, Wood C, Danner D, Sakamoto T, Takita K, Kasumi F, Miki Y, Skolnick M, Nakamura Y: The human prohibitin gene located on chromosome 17q21 is mutated in sporadic breast cancer. Cancer Res 1992;52:1643-1646.

32 Wagner M, Klussmann JP, Fangmann R, Linder R, Elewa ME, Eidt S, Rose VM, Jungehulsing $\mathrm{M}$, Schulze HJ: Cyclin-dependent kinaseinhibitor 1 (CDKN1A) in the squamous epithelium of the oropharynx: Possible implications of molecular biology and compartmentation. Anticancer Res 2001;21:333-345.

33 Menke A, Philippi C, Vogelmann R, Seidel B, Lutz MP, Adler G, Wedlich: Downregulation of E-cadherin expression by collagen type I and type III in pancreatic cancer cell lines. Cancer Res 2001;61:3508-3517.

34 Becker KF, Atkinson MJ, Reich U, Becker I, Nekarda H, Siewert JR and Hofler H: E-cadherin gene mutations provide clues to diffuse type gastric carcinomas. Cancer Res 1994;54: 3845-3852. 